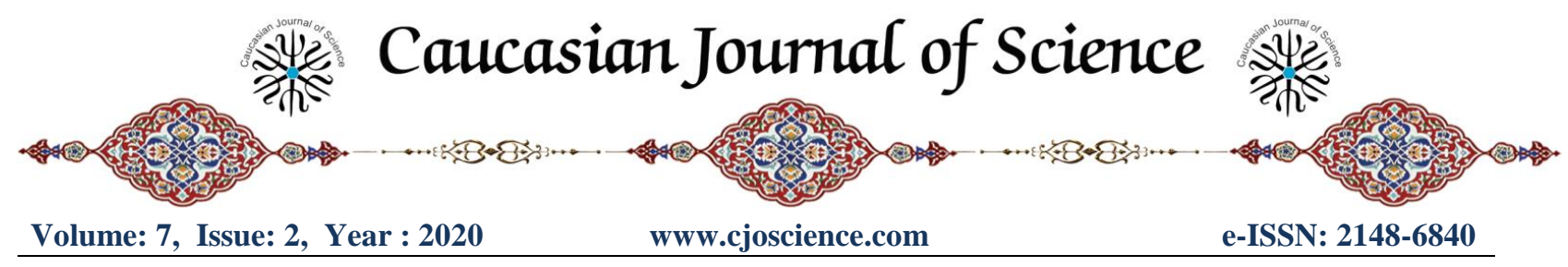

\title{
Determination of Cytotoxicity of Zinc 2-Bromobenzoate with Nicotinamide and $\mathbf{N}, \mathbf{N}^{\prime}$-Diethylnicotinamide Complexes
}

\section{Giray Buğra AKBABA}

Kafkas University, Faculty of Engineering-Architecture, Department of Bioengineering, 36100, Kars, Turkey.

\begin{abstract}
Araştırma Makalesi
Kimya

Geliş Tarihi/Received

Kabul Tarihi/Accepted

Research Article

Chemistry

23.11.2020

30.12.2020

Abstract: Benzoic acid and its derivatives and their metal complexes, which have antimicrobial, anticancer, antituberculosis and antioxidant properties, are biologically active molecules. Although there are many studies on the biological activity of these compounds, studies on the determination of their toxicity are limited. In the presented study, the cytotoxic properties of the previously synthesized diaquabis(2-bromobenzoato- $\mathrm{O}$ )bis(nicotinamide$\kappa N 1) z i n c(I I) \quad(Z n B r B A N A)$ and diaquabis(2-bromobenzoato- $\kappa O) b i s(N, N '-d i e t h y l n i c o t i n a m i d e-\kappa N 1) z i n c(I I)$ (ZnBrBADENA) complexes were investigated. The 3-(4,5-dimethylthiazol-2-yl)-2,5-diphenyltetrazolium bromide (MTT) assay, a colorimetric method, was used to determine the cytotoxicity of complexes on human peripheral lymphocyte cells. Besides, cytotoxicity of dimethylsulfoxide (DMSO) which is crystal solvent and 2-bromobenzoic acid (BrBA), nicotinamide (NA), and N,N'-dietyhlnicotinamide (DENA) which are starting compounds of the complexes was also evaluated. According to the results of MTT method, It has been determined that both complexes and starting components except BrBA cause cytotoxicity on lymphocyte cells at the concentration range of 62.5$500 \mathrm{ppm}$. In addition, it was determined that the BrBA and DMSO at the same concentration range do not show any cytotoxic effect on lymphocyte cells. It was observed that the synthesized complexes were more toxic at each concentration than the starting components. Therefore, the toxic effects of the complexes used as drug active ingredients should be followed up with new studies.
\end{abstract}

Keywords: Cytotoxicity, MTT assay, 2-Bromobenzoic acid, Zinc Complex

\section{INTRODUCTION}

In recent years, the cytotoxic and genotoxic properties of metal complexes and their roles in biological processes have been investigated (Mjos and Orvig, 2014). One of the most important reasons for this is the ability of metal drugs to target to DNA. The biological activity of these compounds depends on their structure and the ligands included. But crystal engineering must take into account any interaction, both weak and strong, to clarify molecular architecture and crystal packaging ( $\mathrm{Lu}$ et al., 2019). Investigation of the relationship between the structure of compounds and their biological activities makes it possible to synthesize new drugs suitable for the purpose (Balan et al., 2020). Zinc complexes attract attention with their crystal structures as well as their biological and physical properties. In recent years, many zinc complexes containing biologically active ligands have been synthesized by different research groups and 
their crystal structures have been investigated (Hökelek et al., 2009; Özbek et al., 2019; Pucci et al., 2013; Sertçelik et al. 2012; 2018; Taşdemir et al., 2016). Zinc (II) complexes are used as DNA binders, tumor photosensitizers, antidiabetic, antifungal, antioxidant and antibacterial agents (Liguori et al., 2010; Pucci et al., 2013). Moreover, in recent studies, Zn (II) complexes have reported that they can be anticancer agents due to their low toxicity and less side effects (Liguori et al., 2010; Pucci et al., 2013).

Metal complexes of benzoic acid and its derivatives have great abilities in various fields (Bakhtiar and Ochiai, 1999; Heine and Müller-Buschbaum, 2013; Krishna, 2015; Li et al., 2013; Rimoldi et al., 2017; Zhu et al., 2017). For the rational design, construction of their supramolecular architecture and properties, auxiliary ligands used as well as the main ligands are also important (Jozef et al., 2016). Used as auxiliary ligands, N-donor heterocyclic compounds are a component of various vitamins and drugs and play an important role in many biological systems. Nicotinamide, the body form of vitamin B3, is a N-donor ligand used in the treatment of some skin diseases. Another N-donor ligand with a similar structure is N,N'diethylnicotinamide, which is used as a respiratory stimulator in medicine (Cavicchi, 1959; Krajníková et al., 2011). While the crystal structure of metal arylcarboxylates with different coligands changes, it is found that the biological activities and toxicity profiles of the complexes change with the change of these ligands (Wang et al., 2020). Drug active ingredients are carried by the blood tissue in the body. Therefore, these active substances first come into contact with blood tissue cells. Therefore, the cytotoxic effects of the two complexes used in this study on lymphocyte cells were investigated. The aim of this study, to determine the cytotoxicity effects of previously synthesized zinc 2-bromobenzoate complexes with nicotinamide and N,N'diethylnicotinamide were used by MTT test method on lymphocyte cells.

\section{MATERIAL AND METHOD}

\subsection{Materials}

The two complexes used in the study were a previously synthesized and their structures were determined (Hökelek et al. 2009a; 2009b). The structures of the complexes were given in Figure 1 and 2. Phosphate Buffered Saline, Antibiotic Antimycotic Solution, L-Glutamine solution, Histopaque-1077 and Dimethylsulfoxide (Sigma-Aldrich), BIOAMF-1 medium and BIOAMF-1 supplement (Biological Industries) and MTT Cell Proliferation Assay Kit (Cayman Chemical) were purchased commercially. Solutions of the complexes at concentrations of 62.5, 125, 250 and 500 ppm were prepared in DMSO. Nüve Steamart OT 40L autoclave, Nüve BM 
101 Water bath, ISOLAB vortex mixer, HETTICH EBA 200 centrifuge device, Panasonic MCO-170AICUVH-PE $\mathrm{CO}_{2}$ Incubator and BioTek Epoch Spectrophotometer were used.

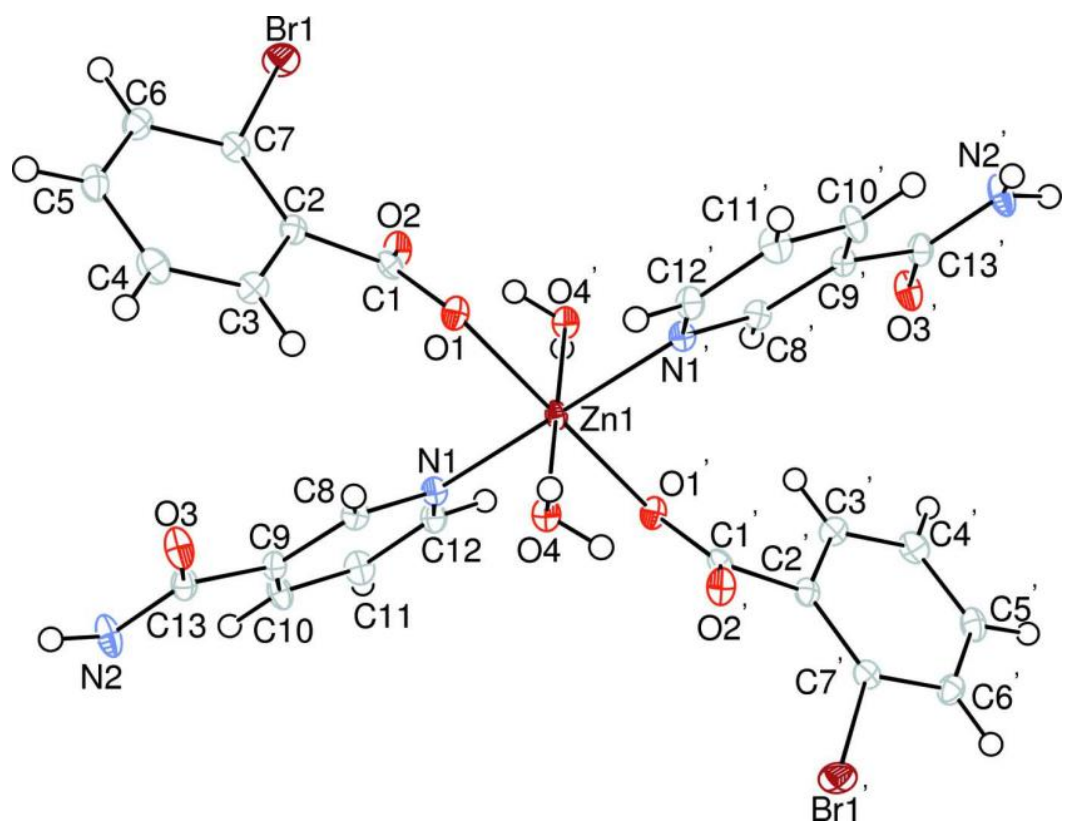

Figure 1. The structure of diaquabis(2-bromobenzoato- $\kappa \mathrm{O})$ bis(nicotinamide- $\left.\mathrm{N}^{1}\right)$ zinc(II)( Hökelek et al., 2009a)

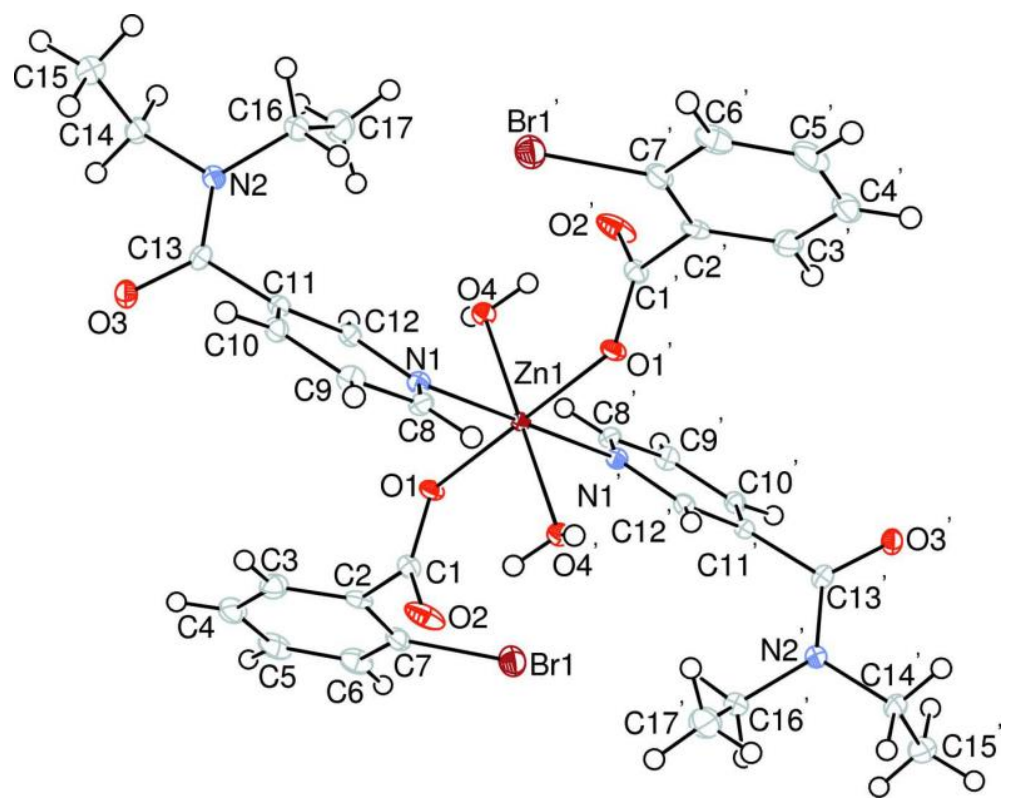

Figure 2. The structure of diaquabis(2-bromobenzoato- $\mathrm{kO})$ bis $\left(\mathrm{N}, \mathrm{N}^{\prime}\right.$-diethylnicotinamide$\kappa \mathrm{N}^{1}$ )zinc(II)( Hökelek et al., 2009b)

\subsection{Method}

Lymphocyte cells to be used in experiments were isolated from a human whole blood sample (Öztürk, 2019) and cell count was done using Thoma slide. The culture medium was 
prepared from the a mixture of amnion cell culture medium $(75 \mathrm{~mL})$, supplement $(15 \mathrm{~mL})$, penicillin + streptomycin + amphotericin B (Antibiotic Antimycotic Solution) $(1.5 \mathrm{~mL})$ and Lglutamine $(2 \mathrm{~mL})$ into a sterile tube. After that culture medium $(100 \mu \mathrm{L})$ and cell suspension $(100 \mu \mathrm{L})(50000$ cells/well $)$ were added to the 96-well plates, respectively. The cells were incubated to proliferate and adhere to the surface for 24 hours in $5 \% \mathrm{CO}_{2}$ incubator at $37{ }^{\circ} \mathrm{C}$. The solutions of the complexes at 500,250,125 and $62.5 \mathrm{ppm}$ concentrations were prepared in DMSO. After $24 \mathrm{~h}$ incubation, $100 \mu \mathrm{L}$ aliquots of different concentrations of the complexes were added to the wells. The cell cultures were incubated at $37{ }^{\circ} \mathrm{C}$ for a day in the incubator. 24 hours later $10 \mu \mathrm{L}$ of MTT reagent was added to each well and the plates were gently mixed on the shaker. Incubation was continued for 3 hours. Formed formazan crystals were seen in the bottom of the wells. Then, the medium in the well was completely removed and $200 \mu \mathrm{L}$ DMSO was added to each well to dissolve the formazan crystals. It was kept in the incubator at $37{ }^{\circ} \mathrm{C}$ for 24 hours. At the end of the incubation, the absorbance values were recorded by $\mathrm{UV}-\mathrm{V}$ is spectrophotometer at $570 \mathrm{~nm}$.

\subsection{Statistical analysis}

The data obtained from tests were analyzed with IBM SPSS statistics for Windows package program (v.18.0, IBM Corp., Armonk, New York, USA). Two-way ANOVA (Tukey) was used to evaluate whether any treatment significantly differed from the control or each other's. Statistically significance level was accepted at \% $95(\mathrm{p}<0.05)$.

\section{RESULTS}

\subsection{MTT Assay}

MTT test is one of the most important pre-screening methods to investigate cell proliferation and anticancer activity of natural products and synthetic materials in the search for new drugs (Jamalian et al., 2011; Mosmann, 1983; Teixeira et al., 2007). In this context, MTT test's results of the complexes, solvent and starting components were assessed. The values of absorbance were recorded at $570 \mathrm{~nm}$ by spectrophotometer. The change in cell viability was compared with the cell control group and percentage of inhibition values were calculated according to the following equation (1). The values were given in Table 1 and Figure 3.

$$
\text { Inhibition percentage }(\%)=\frac{C V}{C V C C} \times 100
$$


$(\mathrm{CV}=$ Cell viability at the test concentrations and $\mathrm{CVCC}=$ Cell viability in cell control $)$

Table 1. Percentage of Cell viability (CV) and Cell death (CD) values at the test concentrations

\begin{tabular}{|c|c|c|c|c|c|}
\hline & & 500 ppm & 250 ppm & 125 ppm & 62,5 ppm \\
\hline \multirow{2}{*}{ Cell Control } & $\mathrm{CV}$ & 100.00 & 100.00 & 100.00 & 100.00 \\
\hline & CD & - & - & - & - \\
\hline \multirow{2}{*}{ DMSO } & $\mathrm{CV}$ & 102.24 & 102.24 & 102.24 & 102.24 \\
\hline & CD & - & - & - & - \\
\hline \multirow{2}{*}{ ZnBrBANA } & $\mathrm{CV}$ & 56.50 & 63.21 & 63.19 & 63.30 \\
\hline & CD & 43.50 & 36.79 & 36.81 & 36.70 \\
\hline \multirow{2}{*}{ ZnBrBADENA } & $\mathrm{CV}$ & 66.03 & 76.23 & 73.32 & 86.01 \\
\hline & CD & 33.97 & 23.77 & 26.68 & 13.99 \\
\hline \multirow{2}{*}{ NA } & $\mathrm{CV}$ & 77.39 & 77.86 & 78.75 & 86.17 \\
\hline & CD & 22.61 & 22.14 & 21.25 & 13.83 \\
\hline \multirow{2}{*}{ DENA } & $\mathrm{CV}$ & 80.68 & 84.57 & 83.93 & 97.88 \\
\hline & CD & 19.32 & 15.43 & 16.07 & 2.12 \\
\hline \multirow{2}{*}{ BrBA } & $\mathrm{CV}$ & 118.75 & 104.80 & 104.42 & 105.00 \\
\hline & CD & - & - & - & - \\
\hline
\end{tabular}

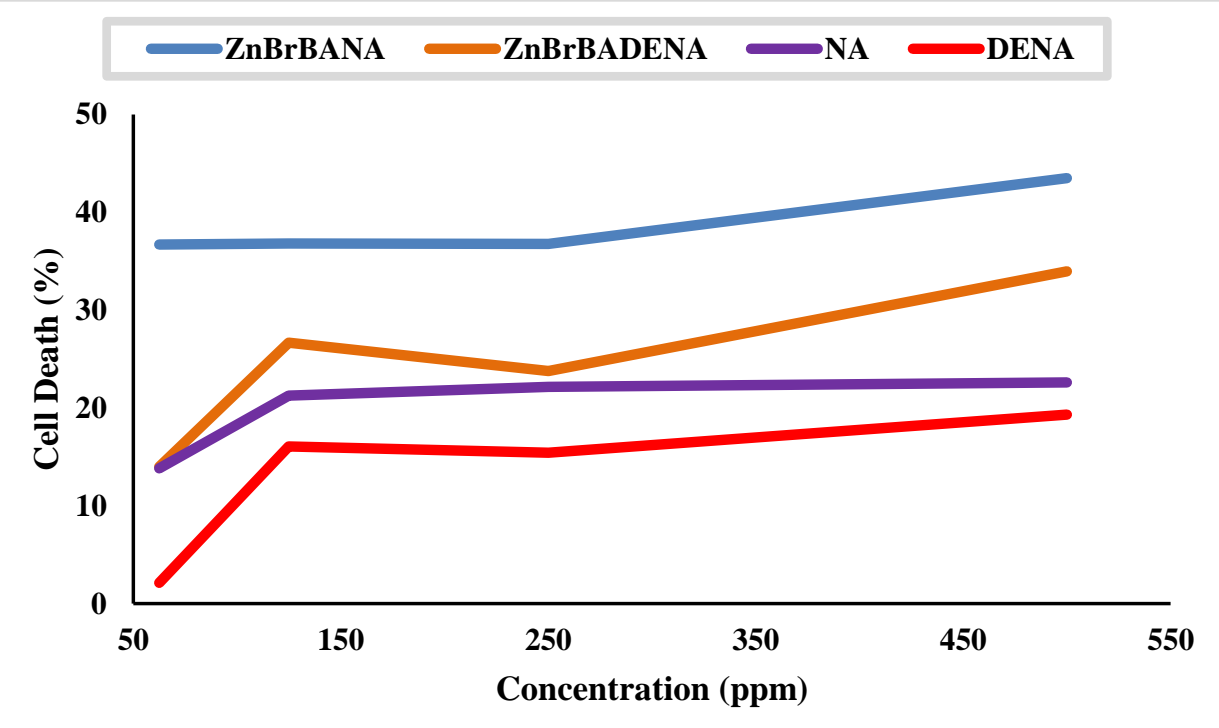

Figure 3. Change in the cell death according to the increasing concentrations

It was determined that DMSO used as solvent did not cause any cell death. Similarly, it was also found that 2-bromobenzoic acid, which is the primary ligand, did not have a cytotoxic effect on lymphocyte cells. NA, the co-ligand in crystal structure of ZnBrBANA, was cytotoxic at all concentrations. While the other co-ligand DENA did not cause cytotoxicity at $62.5 \mathrm{ppm}$, an average of $16.94 \%$ cell death occurred in the 125-500 ppm concentration range. Cytotoxicity of ZnBrBANA and ZnBrBADENA complexes on lymphocyte cells was compared to each other and to the starting compounds (Figure 4-6). According to the results obtained, both complexes 
caused cytotoxicity on these cells at the concentration range of $62.5-500 \mathrm{ppm}$. According to the results obtained, both complexes caused cytotoxicity on these cells at the concentration range of 62.5-500 ppm. ZnBrBANA complex is more toxic at $500 \mathrm{ppm}$ than other concentrations. There is no statistically significant difference at concentrations of 250, 125 and $62.5 \mathrm{ppm}$.

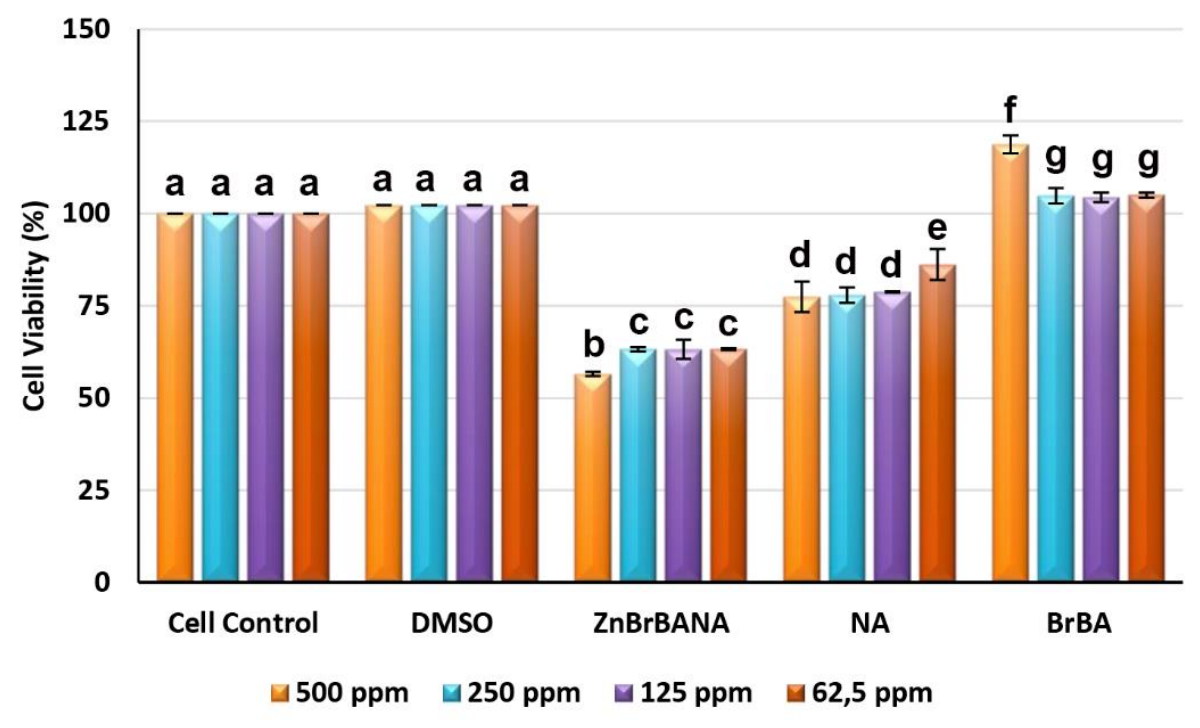

Figure 4. Comparison of cytotoxicity of ZnBrBANA complex with the starting compounds (Different letters on the columns were significantly different at $\mathrm{p}<0.05$ )

Similarly, the ZNBrBADENA complex showed the highest toxicity at $500 \mathrm{ppm}$ concentration. There was no statistically significant difference between the cell death ratios at $125 \mathrm{ppm}$ and $250 \mathrm{ppm}$ of this complex. ZnBrBADENA at $62.5 \mathrm{ppm}$ was determined to cause less toxicity. The cytotoxicity of both complexes increases with the increasing concentration. The toxicity of the ZnBrBANA and ZnBrBADENA complexes compared to each other, the complex containing the DENA ligand was found to be less toxic. It is clear that this is related to the toxicity of the co-ligands contained in the complexes. In some studies, it has been reported that the toxicity of compounds that cause approximately $10 \%$ cell death in normal cells can be neglected and these compounds can be used as anticarcinogenic agents (Bhattacharyya et al., 2019; Nashre-ul-Islam et al., 2019). Since the ZnBrBADENA complex causes $13 \%$ cell death at $62.5 \mathrm{ppm}$, it is thought that it could be used as an anticarcinogenic agent in future studies. There are few studies in the literature on the determination of cytotoxicity of zinc arylcarboxylates with N-donor ligands on lymphocyte cells. 


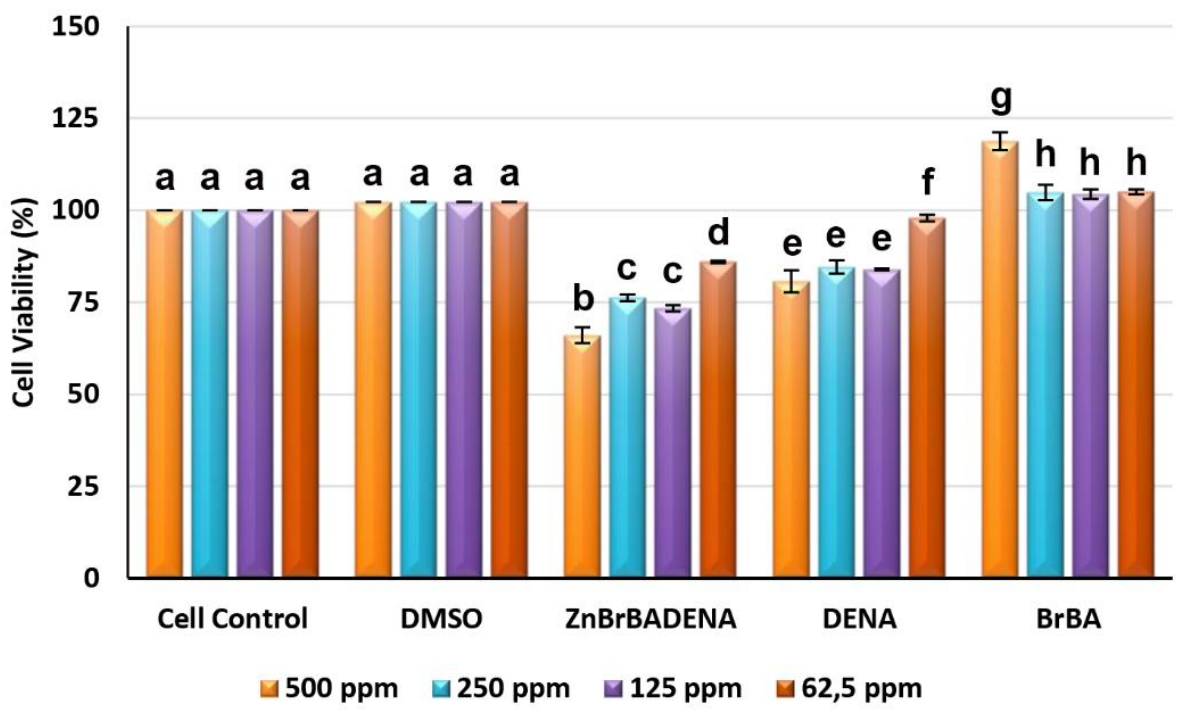

Figure 5. Comparison of cytotoxicity of ZnBrBADENA complex with the starting compounds (Different letters on the columns were significantly different at $\mathrm{p}<0.05$ ).

There is only one study in the literature on the determination of the cytotoxicity of zinc arylcarboxylates with pyridine derivative complexes on normal lymphocyte cells. It was reported that the zinc 2-fluorobenzoic acid nicotinamide complex decreased cell viability with increasing concentration at the 1.17-18.67 mM concentration range (Ozturk and Akbaba, 2019). In addition, it was determined that zinc 2-fluorobenzoate nicotinamide complex caused 13.80$93.58 \%$ cell death in the concentration range of 1250-20000 ppm. Cell death caused by this complex at $10000 \mathrm{ppm}$ is less than the toxicity caused by ZNBrBANA and ZnBrBADENA complexes at 500 ppm (Ozturk and Akbaba, 2019). ZnBrBANA and ZnBrBADENA complexes used in this study caused $43.5 \%$ and $33.97 \%$ cell death at 500 ppm, respectively. Generally, although metal complexes are recommended as an anticarcinogenic drug, their cytotoxic effects on normal cells are not investigated. The two complexes used in this study are not recommended to be used as an anticarcinogenic drug because they cause toxicity on lymphocyte cells at high concentrations (500 ppm). 


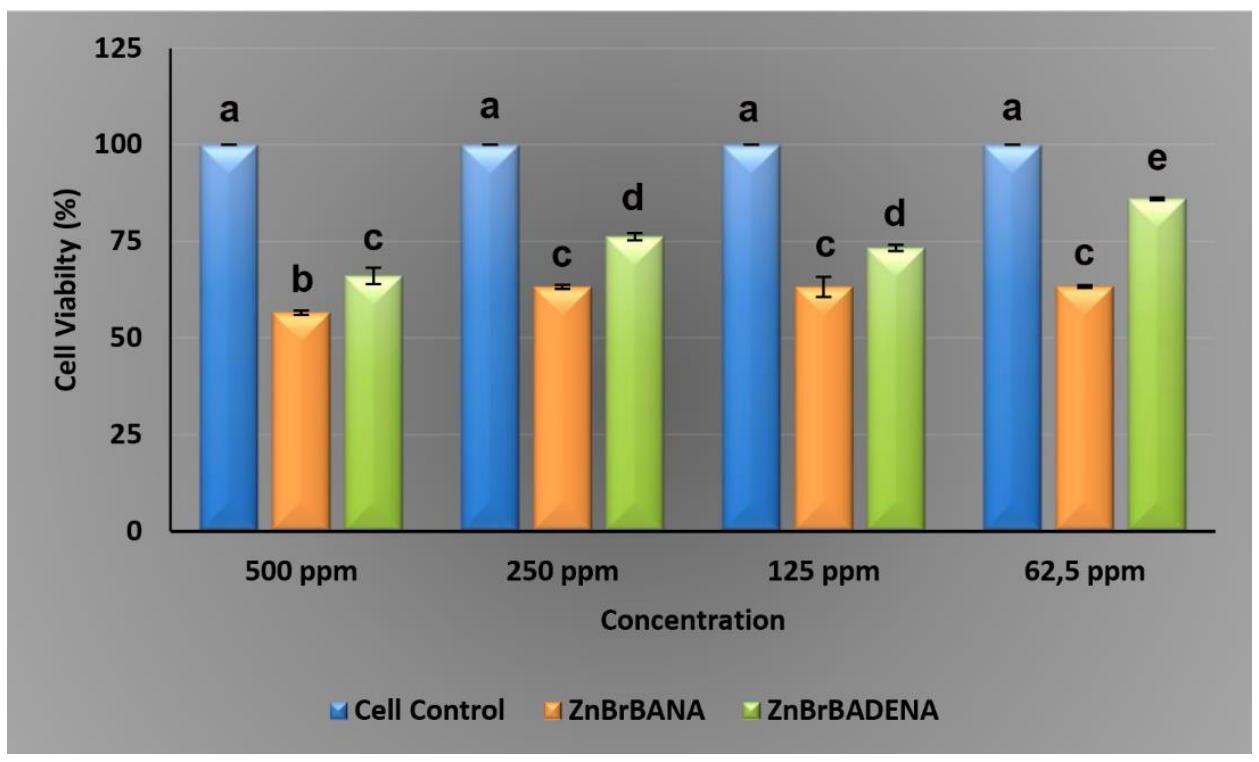

Figure 6. Comparison of cytotoxicity of ZnBrBADENA and ZnBrBANA complexes with cell control (Different letters on the columns were significantly different at $\mathrm{p}<0.05$ ).

\section{CONCLUSION}

It has been supported by many studies that metal arylcarboxylates are biologically active compounds in the last three decades. Although these compounds are recommended for use as new drug active ingredients, they must pass many tests for their active use. In this context, it is essential to know the cytogenotoxicity of the compounds. In many studies, a limited number of studies have been carried out on the toxicity of these compounds, which are stated to be effective against cancer cell lines, on normal cells. In this context, in this study, the cytotoxicity of Zinc (II) 2-bromobenzoate nicotinamide/N,N'-diethylnicotinamide complexes on lymphocyte cells in the concentration range of 62.5-500 ppm was investigated by MTT test. The ZnBrBANA complex was found to be toxic at all concentrations and the ZnBrBADENA complex caused moderate cell death at other concentrations except $62.5 \mathrm{ppm}$. The cytotoxicity of the complexes increases with increasing concentration. At $62.5 \mathrm{ppm}$, the ZnBrBADENA complex is negligible toxic. We propose further studies to evaluate this compound, which causes $13.99 \%$ cell death at this concentration, as DNA binders, tumor photosensitizers, antidiabetic, antifungal, antioxidant and antibacterial agent.

\section{ACKNOWLEDGEMENTS}

I would like to thank Füreya Elif Öztürkkan and Hacali Necefoğlu for their contribution in the supply of the compounds.. 


\section{REFERENCES}

Bakhtiar, R., and Ochiai, E.I. (1999). Pharmacological applications of inorganic complexes. General Pharmacology: The Vascular System, 32(5), 525-540.

Balan, G., Burduniuc, O., Usataia, I., Graur, V., Chumakov, Y., ... (2020). Novel 2-formylpyridine 4-allyl- $S$ methylisothiosemicarbazone and $\mathrm{Zn}(\mathrm{II}), \mathrm{Cu}(\mathrm{II}), \mathrm{Ni}(\mathrm{II})$ and $\mathrm{Co}(\mathrm{III})$ complexes: Synthesis, characterization, crystal structure, antioxidant, antimicrobial and antiproliferative activity. Applied Organometallic Chemistry, 34(3).

Bhattacharyya, M. K., Gogoi, A., Chetry, S., Dutta, D., Verma, A. K., ... Frontera A. (2019). Antiproliferative evaluation and supramolecular association in $\mathrm{Mn}(\mathrm{II})$ and $\mathrm{Zn}(\mathrm{II})$ bipyridine complexes: Combined experimental and theoretical studies. Journal of Inorganic Biochemistry, 200, 110803.

Cavicchi, G. S. (1959). Micro-chemical differentiation of several N, N-diethylamides in pharmaceutical use. Il Farmaco; Edizione Pratica, 14(4), 241-250.

Heine, J., and Müller-Buschbaum, K. (2013). Engineering metal-based luminescence in coordination polymers and metal-organic frameworks. Chemical Society Reviews, 42(24), 9232.

Hökelek, T., Dal, H., Tercan, B., and Özbek F. E., Necefoğlu H. (2009a). Diaquabis(2-bromobenzoato$\kappa O)$ bis(nicotinamide- $\kappa N^{1}$ )zinc(II). Acta Crystallographica Section E Structure Reports Online, 65(5), m607-m608

Hökelek, T., Dal, H., Tercan, B., Özbek, F. E., and Necefoğlu, H. (2009b). Diaquabis(2-bromobenzoato$\kappa O) \operatorname{bis}\left(N, N\right.$-diethylnicotinamide- $\left.\kappa N^{1}\right)$ zinc(II). Acta Crystallographica Section E Structure Reports Online, 65(5), m481-m482.

Hökelek, T., Yılmaz, F., Tercan, B., Sertçelik, M., and Necefoğlu, H. (2009). catena -Poly[[(4-formylbenzoato- $\kappa$ $O^{1}$ )(isonicotinamide- $\left.\kappa N^{1}\right)$ zinc(II)]- $\mu$-4-formylbenzoato- $\kappa^{2} O^{1}: O^{1^{\prime}}$ ]. Acta Crystallographica Section E Structure Reports Online, 65(11), m1399-m1400.

Jamalian, A., Miri, R., Firuzi, O., Amini, M., Moosavi-Movahedi, A. A., and Shafieea, A. (2011). Synthesis, cytotoxicity and calcium antagonist activity of novel imidazolyl derivatives of 1,8-acridinediones. Journal of the Iranian Chemical Society, 8(4), 983-991.

Jozef, H., Danica, Č., Lawson, M. K., Růžičková, Z., Jorík, V., ... Moncol J. (2016). Self-assembly hydrogenbonded supramolecular arrays from copper(II) halogenobenzoates with nicotinamide: Structure and EPR spectrał. Chemical Papers, 70(1).

Krajníková, A., Győryová, K., Hudecová, D., Kovářová, J., and Vargová, Z. (2011). Thermal decomposition and antimicrobial activity of zinc(II) 2-bromobenzoates with organic ligands. Journal of Thermal Analysis and Calorimetry, 105(2), 451-460.

Krishna, R. (2015). Methodologies for evaluation of metal-organic frameworks in separation applications. RSC Advances, 5(64), 52269-52295.

Li, L., Yang, J., Li, J., Chen, Y., and Li, J. (2013). Adsorption and molecular simulation of $\mathrm{CO}_{2}$ and CH4 in twodimensional metal-organic frameworks with the same layered substrate. CrystEngComm, 15(34), 67826789.

Liguori, P. F., Valentini, A., Palma, M., Bellusci, A., Bernardini, S., ... Pucci D. (2010). Non-classical anticancer agents: synthesis and biological evaluation of zinc(II) heteroleptic complexes. Dalton Transactions, 39(17), 4205 
Lu, Y., Xu, W., Hu, K., Jin, S., Sun, L., Liu, B., and Wang D. (2019). Synthesis and structural characterizations of nine non-covalent-bonded $\mathrm{Zn}^{2+}$, and $\mathrm{Cd}^{2+}$ supramolecules based on 3,5-dimethylpyrazole and carboxylates. Polyhedron, 159, 408-425.

Mjos, K. D., and Orvig, C. (2014). Metallodrugs in Medicinal Inorganic Chemistry. Chemical Reviews, 114(8), $4540-4563$

Mosmann, T. (1983). Rapid colorimetric assay for cellular growth and survival: Application to proliferation and cytotoxicity assays. Journal of Immunological Methods, 65(1), 55-63.

Nashre-ul-Islam, S. M, Dutta, D., Verma, A. K., Nath, H., Frontera, A., Sharma, P., and Bhattacharyya M. K. (2019). Antiproliferative evaluation and supramolecular association involving electrostatically enhanced $\pi-\pi$ interaction in isostructural coordination solids of $\mathrm{Mn}(\mathrm{II}), \mathrm{Co}$ (II) and $\mathrm{Zn}(\mathrm{II})$ chlorobenzoates: Experimental and theoretical studies. Inorganica Chimica Acta, 498, 119161.

Ozturk, C., and Akbaba, G. B. (2019). Investigation of Antibacterial and Cytotoxic Properties of Mix Ligand Complex of Zinc 2-Fluorobenzoate with Nicotinamide. Hittite Journal of Science \& Engineering, 6(4), 269-274.

Özbek, F. E., Sertçelik, M., Yüksek, M., Uğurlu, G., Tonbul, A. M., Necefoğlu, H., and Hökelek T. (2019). Synthesis and Crystallographic, Absorption and Emission Studies of 4-Pyridine Carboxamide of $\mathrm{Zn}(\mathrm{II})$ 4-Chlorophenylacetate. Journal of Fluorescence, 29(5), 1265-1275.

Öztürk, C. (2019). Çinko 2-Florobenzoatın Nikotinamid ile Mix Ligant Kompleksinin Antibakteriyel ve Sitotoksik Özelliklerinin İncelenmesi. Yüksek Lisans Tezi, Kafkas Üniversitesi, Fen Bilimleri Enstitüsü, Kars.

Pucci, D., Crispini, A., Mendiguchía, B.S., Pirillo, S., Ghedini, M., Morelli, S., and De Bartolo L. (2013). Improving the bioactivity of $\mathrm{Zn(ii)-curcumin} \mathrm{based} \mathrm{complexes.} \mathrm{Dalton} \mathrm{Transactions,} \mathrm{42(26),} \mathrm{9679-9687.}$

Rimoldi, M., Howarth, A. J., DeStefano, M. R., Lin, L., Goswami, S., .. Farha, O.K. (2017). Catalytic Zirconium/Hafnium-Based Metal-Organic Frameworks. ACS Catalysis, 7(2), 997-1014.

Sertçelik, M., Çaylak Delibaş, N., Necefoğlu, H., and Hökelek T. (2012). Diaquabis( $N, N$-diethylnicotinamide$\left.\kappa N^{1}\right)$ bis(4-formylbenzoato- $\left.\kappa O^{1}\right)$ zinc. Acta Crystallographica Section E Structure Reports Online, 68(8), m1067-m1068.

Sertçelik, M., Özbek, F. E., Sugeçti, S., and Necefoğlu H. (2018). Synthesis Of Izonicotınamide Complexes Of 4Formilbenzoate with Co (II), Cu (II) And Zn (II); Investigation of Spectroscopic, Thermal Properties and Antibacterial Activities. Journal of the Institute of Science and Technology, 8(4), 189-195.

Taşdemir, E., Özbek, F. E., Sertçelik, M., Hökelek, T., Çelik, R. Ç., and Necefoğlu H. (2016). Supramolecular complexes of $\mathrm{Co}(\mathrm{II}), \mathrm{Ni}(\mathrm{II})$ and $\mathrm{Zn}(\mathrm{II})$ p-hydroxybenzoates with caffeine: Synthesis, spectral characterization and crystal structure. Journal of Molecular Structure, 1119, 472-478.

Teixeira, R., Barbosa, L., Maltha, C., Rocha, M., Bezerra, D., ... Moraes M.O. (2007). Synthesis and Cytotoxic Activity of Some 3-Benzyl-5-Arylidenefuran-2(5H)-ones. Molecules, 12(5), 1101-1116.

Wang, D., Liu, X., Ye, X., Yuan, K., Xing, X., ... Wu D. (2020). Synthesis of low toxicity metal-organic framework carrier for drug release. Materials Express, 10(6), 934-941.

Zhu, Z., Xu, C., Wang, M., Zhang, X., Wang, H., ... Fan Y. (2017). Six Co(II) Coordination Polymers Based on Two Isomeric Semirigid Ether-Linked Aromatic Tetracarboxylate Acid: Syntheses, Structural Comparison, and Magnetic Properties. Crystal Growth \& Design, 17(10), 5533-5543. 